\title{
Apolipoprotein E Measurement
}

National Cancer Institute

\section{Source}

National Cancer Institute. Apolipoprotein E Measurement. NCI Thesaurus. Code C82002.

The determination of the amount of apolipoprotein E present in a sample. 